\title{
Analysis of Economic Structure and Leading Sectors in Rejang Lebong District
}

\author{
Anadiya Pingki, Bambang Sumantri, and Ketut Sukiyono* \\ Department of Agricultural Socio-Economics, Faculty of Agriculture, University of Bengkulu \\ * Coresponding author: ksukiyono@unib.ac.id
}

\begin{abstract}
This study aims to determine and analyse the economic structure and leading sectors in Rejang Lebong Regency. The data used is secondary data on Gross Regional Domestic Product from 2015 to 2019 obtained from the Central Statistics Agency. The analysis used is economy structure, Location Quotient (LQ), Dynamic Location Quotient (DLQ), Shift-share, and Overlay. The results show that the highest GRDP contributor is the Agriculture, Fisheries, and Forestry sectors while the lowest is the Electricity and Gas Procurement sector with contribution of $32 \%$ and $0.15 \%$ respectively. The results of the leading economic sectors in the Rejang Lebong Regency are the sectors of Agriculture, Forestry and Fisheries, Providing Accommodation and Food and Drink; Defense and Compulsory Social Security; Education Services; Health Services and Other Services.
\end{abstract}

Key words: LQ, DLQ, Shiftshare, leading Sector

Reference to this paper should be made as follows:

Pinki, A., B. Sumantri, K. Sukiyono. 2021. Analysis of Economic Structure and Leading Sectors in Rejang Lebong District. Agritropica: Journal of Agricultural Science. 4 (1): 8 - 19. DOI: https://doi.org/10.31186/Jagritropica.4.1.8-19.

\section{INTRODUCTION}

Indonesia is a developing country that focuses on national economic development. Economic development is through economic growth efforts related to increased production of goods and services. The implementation of national development has an impact on regional development because regions are part of a country. Indonesia is a unitary state, so its development includes national development and regional development. Regional economic development is the process by which local governments and communities manage the resources that exist in the area concerned. Natural resource management forms a cooperation between local governments and sectors to create jobs. This cooperation can provide a stimulus to regional economic growth (Arsyad, 2010).
Regional economic development is carried out more specifically because regional economic growth is a benchmark for the economy in an area to realize economic development (Sincere, 2003). Good planning will affect the success of economic development in an area. To achieve development success, it is necessary to pay attention to the economic structure of the area. Economic potential is the economic capacity possessed by an area that may or is feasible to be developed. This potential can help the regional economy as a whole to develop independently and sustainably (Soeparmoko, 2002). One of the provinces that have good economic growth is Bengkulu Province.

Bengkulu Province is one of the provinces that has a good GRDP value. In 2015-2019 the GRDP value according to the 
business field of Bengkulu Province has increased continuously.

This shows that the economic growth is also influenced by the districts/cities in Bengkulu Province. One such regency is Rejang Lebong Regency.

Rejang Lebong Regency has a GRDP value based on the current price in 2019 reaching IDR 9.37 trillion. This PDRB value has increased compared to 2018 which was only IDR 8.69 trillion. The increase in the value of GRDP is influenced by increased production in all business fields and inflation. Based on constant 2010 prices, the GRDP figure also increased from IDR 5.79 trillion in 2018 to IDR 6.08 trillion in 2019 (BPS, 2019).

The analysis was carried out to find out how the economic structure and what sectors will be the leading sectors in Rejang Lebong Regency so that these sectors can help economic growth in Rejang Lebong Regency.

\section{MATERIALS AND METHODS}

Many regional economic models that can be used can be used in analyzing regional economic issues, including the economic base model, the input-output model (I-O model), the social accounting matrix (SAM), and the computable general equilibrium (CGE) (Sukiyono, 2010). The economic base method used in this research is a quantitative method that uses trend analysis, Location Quotient (LQ), Dynamic Location Quotient (DLQ), Shiftshare, and Overlay. The data used in this study are secondary data on the Gross Regional Domestic Product for 2015-2019 Rejang Regency and the 2015-2019 Gross Regional Domestic Product for Bengkulu Province, which was obtained through the website of the Central Statistics Agency.

\section{Analysis of Economy Structure}

The economic structure analysis in this study was analyzed descriptively. The economic structure is depicted through a bar graph with GRDP data by business field in percent. GRDP depicted based on current prices and constant prices in 2010 in 2015-2019 in Rejang Lebong Regency.

\section{Location Quotient (LQ) Analysis}

Location Quotient is the analysis method used for identifying the leading sector (base) and not the leading sector (non-base) Rejang Lebong Regency compared to the contribution of the sectors and subsectors of the same economy in Bengkulu Province. The calculation uses the formula:

$$
\mathrm{LQ}=\frac{\mathrm{Si} / \mathrm{S}}{\mathrm{Ni} / \mathrm{N}}
$$

From the results of this LQ calculation, it can be seen that if:

1. LQ of a sector $>1$, then the sector is the base sector or source of growth. The results not only meet the needs of the region but also outside the region.

2. LQ of a sector $<1$, then the sector is a non-basic sector. Production of a commodity can only meet the needs of the region itself, so it needs supplies from outside.

3. LQ of a sector $=1$, so there is a tendency for the sector to be closed because it does not make transactions to and from outside the region (Widodo, 2006).

\section{Dynamic Location Quotient (DLQ) Analysis}

Dynamic Location Quotient (DLQ) analysis is used to determine future repositioning of sectors and subsectors in a particular area. This analysis is important to use to determine whether in the future certain sectors and subsectors can survive as a sector and sub-sector basis or not and 
vice versa whether the sectors and subsectors that were previously not the basis can experience reposition have the potential to become basic sectors and subsectors in future (Hajeri et al, 2015). According to Suyatno (2000) and Isabhandia et al, 2021), the formula for the DLQ is as follows:

$$
\mathrm{DLQ}=\frac{(1+\mathrm{gij}) /(1+\mathrm{gj})}{(1+\mathrm{Gi}) /(1+\mathrm{G})} \mathrm{t}
$$

The criteria for the decision of the DLQ value are as follows:

1. The value of DLQ> 1 means that a sector can still be expected to become a base sector in the future.

2. DLQ value $<1$ means that the sector cannot be expected to become a base sector in the future.

\section{LQ and DLQ Analysis}

To see the position experienced by the sector in Rejang Lebong Regency, a combined analysis of the LQ and DLQ methods is used, with the following conditions according to Hajeri et al (2015):

Decision-making criteria:

1. LQ $<1$ and DLQ $>1$ means that the sector is repositioned into a base sector in the future (base reposition).

2. $\mathrm{LQ}>1$ and $\mathrm{DLQ}<1$, mean that the sector is repositioned into a nonbasic sector in the future (non-basis repositioning).

3. $L Q>1$ and DLQ> 1 means that the sector has not experienced repositioning or remains on the current and future basis.

4. $\mathrm{LQ}<1$ and DLQ $<1$, then the sector is not experiencing repositioning or non-basis today and in the future.

\section{Shift Share Analysis}

Shift-Share is an analysis to determine the occurrence of a shift in the share of economic sectors and to determine the comparative advantage in economic sectors in the analysis area. According to (Hajeri et al, 2015), the formulae and components in the shift-share analysis are as follows:

1. The real impact of economic growth

Information :

$$
\mathrm{Dij}=\mathrm{Nij}+\mathrm{Mij}+\mathrm{Cij}
$$

$\mathrm{I}=$ Economic sectors studied

$\mathrm{J}=$ Variable area under study (Rejang Lebong Regency)

$\mathrm{N}=$ National area variable (Bengkulu Province)

Dij= Change in sector $\mathrm{i}$ in area $\mathrm{j}$ (Rejang Lebong Regency)

$\mathrm{Nij}=$ National growth sector $\mathrm{i}$ in area j (Rejang Lebong Regency)

Mij = Industry mix of sector $\mathrm{i}$ in area j (Rejang Lebong Regency)

Cij = Competitive advantage of sector $i$ in area $j$ (Rejang Lebong Regency)

2. The effect of economic growth

$$
\mathrm{Nij}=\text { Eij } \mathrm{x} \mathrm{rn}
$$

Information: $\mathrm{rn}=$ Provincial growth rate

3. Proportional shift:

Description:

$$
\text { Mij = Eij }(\text { rin }-r n)
$$

$\mathrm{rn}=$ The rate of growth in the province of East Java

rin $=$ the growth rate of the agricultural sector in the province of East Java 
4. Influence on a competitive basis

Information:

$$
\mathrm{Cij}=\mathrm{Eij}(\mathrm{rij}-\mathrm{rin})
$$

$$
\begin{aligned}
\mathrm{Cij}= & \text { Value of competitive } \\
& \text { advantage component } \\
\mathrm{Eij}= & \text { The value of the agricultural } \\
& \text { sector in the Kota Batu area } \\
& \text { at the beginning of the } \\
& \text { analysis year }
\end{aligned}
$$

The decision criteria that can be taken for the Shift Share value are:

1. If the value $(\mathrm{N})$ is positive, it means that sector $i$ in Rejang Lebong Regency is growing faster than the average growth of Bengkulu Province. Conversely, if the value $(\mathrm{N})$ is negative, it means that sector $i$ in Rejang Lebong Regency is growing slower than the average growth of Bengkulu Province.

2. If the value (M) is positive, it means that sector $\mathrm{i}$ is advanced, and that sector is growing faster than the overall economic growth. Conversely, if the value (M) is negative, it means that sector $i$ is a sector that is growing slowly.

3. If the value $(\mathrm{C})$ is positive, it means that sector $i$ have high competitiveness in Rejang Lebong Regency. Conversely, if the value (C) is negative, it means that sector I has no competitiveness in Rejang Lebong Regency.

\section{Overlay Analysis}

This method is used to see the combination of several analysis tools used, namely Location Quotient (LQ) analysis,
Dynamic Location Quotient (DLQ), and Shift Share, in determining the leading sectors in Rejang Lebong Regency. The coefficients of the three analyzes must be equated with a positive $(+)$ and negative $(-)$ sign. If the values of LQ and DLQ> 1 (positive) and $<1$ (negative). For shiftshare, if the proportional and differential shift values are both positive and negative, the result is negative. Identify on the overlay if the three analysis tools are positive $(+)$, then the sector is a leading sector.

\section{RESULTS AND DISCUSSION}

\section{Analysis of Economy Structure}

The results of the analysis show that the sectors with the highest value are in the Agriculture, Fisheries and Forestry sectors. This happens because Rejang Lebong Regency is located in the highlands, which is part of the area that produces horticultural and plantation commodity crops.

1. Economic Structure of Rejang Lebong Regency based on 20152019 current price.

Gross Regional Domestic Product is the gross added value of all goods and services in a region. These goods and services can generate added value through various economic activities in a certain period. The current price is GRDP based on the prevailing price in the applicable calculation period and aims to see the structure of the economy. The entire GRDP value of the 17 sectors in Rejang Lebong Regency can be illustrated in the bar graph below: 


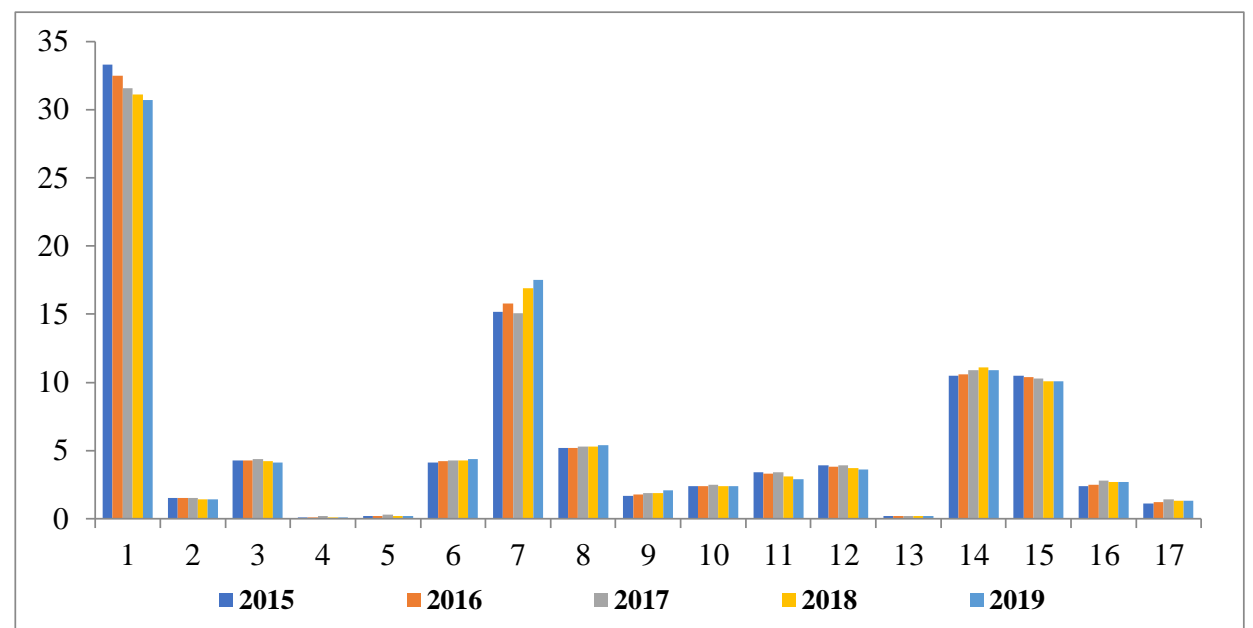

Figure 1. Economic Structure of GRDP at the Current Price of Rejang Lebong Regency in 2015-2019

The bar graph above shows that the highest GRDP value is found in the agricultural sector. This happens because it is known that the GRDP value of the agricultural sector is always the highest, ranging from $30.7 \%$ - 33.3\%. Rejang Lebong Regency is one of the districts that have good potential in the agricultural sector. Rejang Lebong Regency produces horticultural crops in the commodity of red chilies, shallots, garlic, leeks, potatoes, cabbage, carrots, tomatoes, and eggplants in large quantities. For the types of plantation crops, Rejang Lebong Regency produces coffee and cocoa commodities. Not only horticultural and plantation crops, but Rejang Lebong Regency also produces fruit types. The fruits produced in Rejang Lebong Regency are oranges, mangoes, durian, avocado, papaya, salak, and rambutan.

The lowest GRDP value against the current price is found in the electricity and gas procurement sector, which has a value for the last five years only at the point of $0.1 \%-0.2 \%$. This shows that the electricity and gas procurement sector has not been able to contribute a high GRDP value to the economy of the Rejang Lebong Regency.
2. Economic Structure of Rejang

Lebong Regency based on 2010

Constant Prices.

Gross Regional Domestic Product is the gross added value of all goods and services in a region. These goods and services can generate added value through various economic activities in a certain period. Gross Regional Domestic Product (GRDP) at constant prices is the price used in a particular base year which is the basis or reference. This discussion explains the GRDP data at constant prices, from 20152019. The entire GRDP value of the 17 sectors in Rejang Lebong Regency can be illustrated in the bar graph below.

The bar graph below shows that the highest GRDP value is found in the agricultural sector. This happens because it is known that the GRDP value of the agricultural sector is always the highest, ranging from $29.7 \%$ - 32.2\%. Rejang Lebong Regency is one of the districts that has good potential in the agricultural sector. Rejang Lebong Regency produces horticultural crops in the commodity of red chilies, shallots, garlic, leeks, potatoes, cabbage, carrots, tomatoes, and eggplants which have large quantities. Apart from the types of horticultural crops, Rejang Lebong Regency also produces types of plantation crops. These types of plants are 


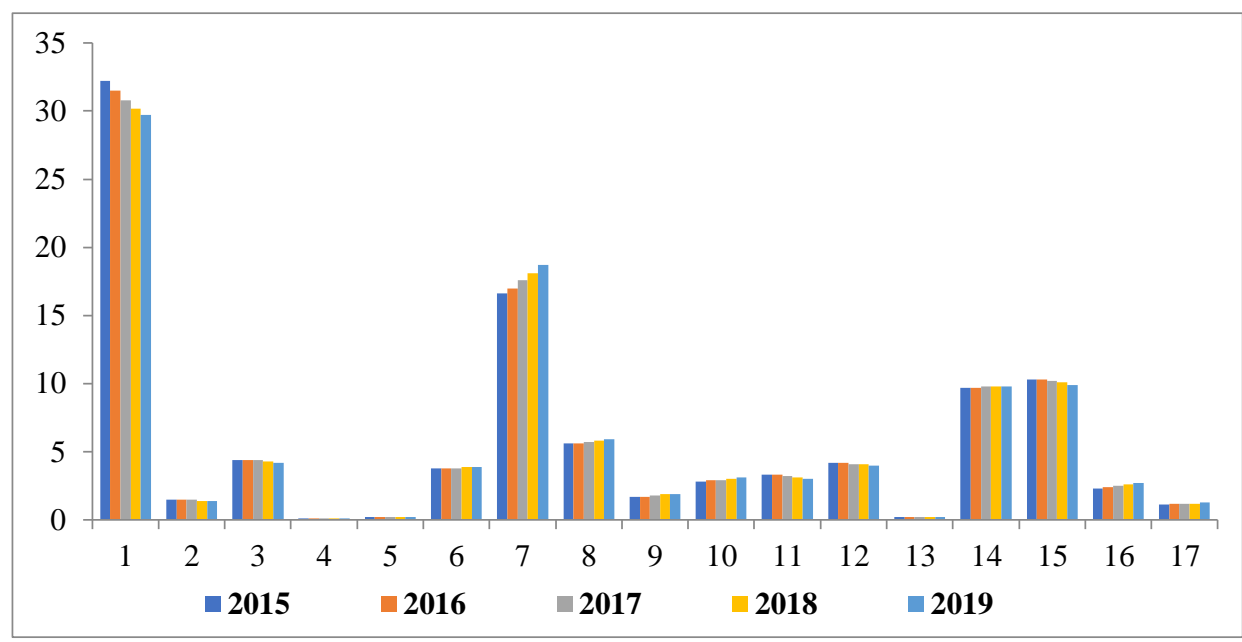

Figure 2. Economic Structure of GRDP based on constant prices in Rejang Lebong Regency 2015-2019

found in coffee and cocoa commodities. Not only horticultural and plantation crops, but Rejang Lebong Regency also produces fruit types.

GRDP Value based on constant 2010 prices in Rejang Lebong Regency from 2015-2019 which is written in percent $(\%)$, it is known that the lowest value is found in the electricity and gas procurement sector. during the last five years, this sector only had a GRDP value of $0.1 \%$. This shows that the electricity and gas procurement sector has not been able to contribute a high amount of GRDP to the economy in Rejang Lebong Regency.

\section{LQ Analysis}

To determine the basic and nonbasic sectors, LQ analysis is used. The analysis uses secondary data on GRDP in each economic sector in Rejang Lebong Regency and Bengkulu Province. The results of LQ calculations in Rejang Lebong Regency in this study can be seen in the following table 1 .

It is known that the results of the LQ analysis in Rejang Lebong Regency in 2015-2019 were eight sectors which were the basic sectors because they had an LQ value $>1$. These sectors are the Agriculture, Forestry and Fisheries sectors;
Procurement of Electricity and Gas; Wholesale and Retail Trade; Repair; Provision of accommodation and food and drink; Mandatory Government Administration, Defense and Social Security; Education Services; Health Services and Other Services.

The first sector which becomes the base sector is agriculture, fisheries, and forestry. This sector is one of the sectors that makes a big contribution to economic development in the Rejang Lebong Regency because it can be seen that Rejang Lebong Regency is one of the districts that has a high geographical surface. The location is capable of being a place to grow various types of plant commodities, ranging from types of horticultural and plantation commodities. The results of the LQ analysis on this sector are similar to the research conducted by Situmorang et al (2020) which has an LQ value> 1 . This shows that the sector can contribute high GRDP value to Rejang Lebong Regency. The next sector is the electricity and gas procurement sector, This sector is a contributor to the relatively high GRDP value compared to other districts in Bengkulu Province. This has resulted in this sector being able to become a basic sector. The same is true for the wholesale 
and retail trade sector; Repair; Provision of accommodation and food and drink; Mandatory Government Administration,
Defense, and Social Security; Education Services; Health Services and Other Services.

Table 1. Value of LQ in Rejang Lebong Regency

\begin{tabular}{|c|c|c|c|c|c|c|c|c|}
\hline \multirow{2}{*}{ No } & \multirow{2}{*}{ Sectors } & \multicolumn{5}{|c|}{ LQ } & \multirow{2}{*}{$\begin{array}{c}\text { Avera } \\
\text { ge }\end{array}$} & \multirow{2}{*}{$\begin{array}{c}\text { Classificatio } \\
\mathrm{n}\end{array}$} \\
\hline & & 2015 & 2016 & 2017 & 2018 & 2019 & & \\
\hline 1 & $\begin{array}{l}\text { Agriculture, Forestry, } \\
\text { and Fisheries }\end{array}$ & 1.10 & 1.09 & 1.08 & 1.08 & 1.08 & 1.09 & Base \\
\hline 2 & Mining and Quarrying & 0.40 & 0.41 & 0.41 & 0.41 & 0.41 & 0.41 & Non-base \\
\hline 3 & Processing industry & 0.70 & 0.70 & 0.70 & 0.70 & 0.70 & 0.70 & Non-base \\
\hline 4 & $\begin{array}{l}\text { Procurement of } \\
\text { Electricity and Gas }\end{array}$ & 1.02 & 1.01 & 1.01 & 1.01 & 1.02 & 1.01 & Base \\
\hline 5 & $\begin{array}{l}\text { Water Supply; Waste, } \\
\text { Waste and Recycling } \\
\text { Management }\end{array}$ & 0.83 & 0.83 & 0.83 & 0.83 & 0.82 & 0.83 & Non base \\
\hline 6 & $\begin{array}{l}\text { Construction } \\
\text { Wholesale and Retail }\end{array}$ & 0.86 & 0.86 & 0.86 & 0.86 & 0.84 & 0.85 & Non-base \\
\hline 7 & $\begin{array}{l}\text { Trade; Car and } \\
\text { Motorcycle Repair }\end{array}$ & 1.14 & 1.14 & 1.14 & 1.14 & 1.15 & 1.14 & Base \\
\hline 8 & $\begin{array}{l}\text { Transportation and } \\
\text { Storage }\end{array}$ & 0.71 & 0.72 & 0.72 & 0.72 & 0.72 & 0.72 & Non-base \\
\hline 9 & $\begin{array}{l}\text { Provision of } \\
\text { Accommodation and } \\
\text { Food and Drink }\end{array}$ & 1.11 & 1.11 & 1.11 & 1.12 & 1.10 & 1.11 & Base \\
\hline 10 & $\begin{array}{l}\text { Information and } \\
\text { Communication }\end{array}$ & 0.66 & 0.66 & 0.66 & 0.66 & 0.66 & 0.66 & Non-base \\
\hline 11 & $\begin{array}{l}\text { Financial Services and } \\
\text { Insurance }\end{array}$ & 0.96 & 0.96 & 0.97 & 0.98 & 1.00 & 0.97 & Non-base \\
\hline 12 & Real Estate & 0.92 & 0.92 & 0.92 & 0.92 & 0.92 & 0.92 & Non-base \\
\hline 13 & $\begin{array}{l}\text { Company Services } \\
\text { Mandatory } \\
\text { Government }\end{array}$ & 0.07 & 0.07 & 0.07 & 0.07 & 0.07 & 0.07 & Non-base \\
\hline 14 & $\begin{array}{l}\text { Administration, } \\
\text { Defense, and Social } \\
\text { Security }\end{array}$ & 1.11 & 1.11 & 1.11 & 1.11 & 1.10 & 1.11 & Base \\
\hline 15 & Education Services & 1.61 & 1.61 & 1.61 & 1.61 & 1.60 & 1.61 & Base \\
\hline 16 & Health Services & 1.56 & 1.56 & 1.55 & 1.55 & 1.54 & 1.55 & Base \\
\hline 17 & Other Services & 1.57 & 1.55 & 1.51 & 1.51 & 1.51 & 1.53 & Base \\
\hline
\end{tabular}

Source: Processed data, 2021.

The basic sector in Rejang Lebong Regency illustrates that this sector is able to meet the needs of the Rejang Lebong Regency as a source of economic growth and the results not only meet the needs of the region but also outside the region. The same is true for the wholesale and retail trade sector; Repair; Provision of accommodation and food and drink; Mandatory Government Administration, Defense, and Social Security; Education Services; Health Services and Other Services. The basic sector in Rejang Lebong Regency illustrates that this sector is able to meet the needs of the Rejang Lebong Regency as a source of economic growth 
and the results not only meet the needs of the region but also outside the region. The same is true for the wholesale and retail trade sector; Repair; Provision of accommodation and food and drink; Mandatory Government Administration, Defense, and Social Security; Education Services; Health Services and Other Services. The basic sector in Rejang Lebong Regency illustrates that this sector is able to meet the needs of the Rejang Lebong Regency as a source of economic growth and the results not only meet the needs of the region but also outside the region.

\section{DLQ Analysis}

Dynamic Location Quotient (DLQ) analysis is used to determine whether a sector in the future will still survive as a base sector or not, even if it was not a basis previously, it will experience repositioning to become a base sector (Hajeri et al, 2015). In the table above, it can be seen that the DLQ value $>1$ and the DLQ value $<1$. It can be seen that the sectors that have a DLQ value> 1 are in the Agriculture, Forestry and Fisheries sectors; Water Supply; Waste, Waste and Recycling Management; Construction; Provision of accommodation and food and drink; Real Estate; Company Services; Mandatory Government Administration, Defense, and Social Security; Education Services; Health Services and Other Services. This shows that the sector is considered a Basic or is able to meet the economic needs of the Rejang Lebong Regency and even leaves the region with time or in the future.

Table 2. DLQ Analysis Results

\begin{tabular}{llcl}
\hline No. & Sector & Average & Information \\
\hline 1 & Agriculture, Forestry, and Fisheries & 1.28 & Base \\
2 & Mining and Quarrying & 0.35 & Non-Base \\
3 & Processing industry & 0.86 & Non-Base \\
4 & Procurement of Electricity and Gas & 0.91 & Non-Base \\
5 & Water Supply; Waste, Waste and Recycling & 1.53 & Base \\
6 & Management & 1.31 & Base \\
7 & Wonstruction & 0.80 & Non-Base \\
8 & and Motorcycles & 0.78 & Non-Base \\
9 & Transportation and Storage & 1.03 & Base \\
10 & Provision of Accommodation and Food and Drink & 0.95 & Non-Base \\
11 & Financial Services and Insurance & 0.22 & Non-Base \\
12 & Real Estate & 1.12 & Base \\
13 & Company Services & 1.39 & Base \\
14 & Mandatory Government Administration, Defense, & 1.12 & Base \\
15 & and Social Security & 1.07 & Base \\
16 & Education Services & 1.09 & Base \\
17 & Other Services & 1.50 & Base \\
\hline
\end{tabular}

Source: Processed data, 2021 


\section{Combined LQ and DLQ analysis}

The combined analysis of LQ and DLQ is an analysis carried out to determine whether the sector which was originally based remains a persistent basis for the future or vice versa.

The table above shows the LQ and DLQ values for each sector in Rejang Lebong Regency. Two sectors remain the basis based on the analysis of LQ and DLQ. These sectors are Agriculture, Forestry and Fisheries, and Provision of Food and Drinking Accommodations. This shows that the sector is able to meet the economic needs of the region and outside the region, both in the present and in the future. The agriculture, fisheries, and forestry sectors are sectors that can maintain the present and future economic conditions because the agricultural sector is one of the sources of livelihood for the community in the Rejang Lebong Regency, especially in the Selupu Rejang District area. As a source of livelihood, the land in the area is still used as land for planting horticultural and plantation plant commodities. As well as this sector is able to meet the needs of the region and outside the region.

The same thing also happened to the food and drink accommodation provision sector. This sector has a good GRDP value so that it can meet the economic needs of the Rejang Lebong Regency and outside the region in the present and the future. This sector can maintain its position as a Basic sector in helping the economic growth of the Rejang Lebong Regency. This high GRDP is obtained from the added value and services produced by the two sectors.

Table 3. Combined Results of LQ and DLQ analysis

\begin{tabular}{|c|c|c|c|c|}
\hline No. & Sector & LQ & DLQ & Information \\
\hline 1 & Agriculture, Forestry, and Fisheries & 1.09 & 1.28 & Stay Base \\
\hline 2 & Mining and Quarrying & 0.41 & 0.35 & Non-Base \\
\hline 3 & Processing industry & 0.70 & 0.86 & Non-Base \\
\hline 4 & Procurement of Electricity and Gas & 1.01 & 0.91 & Non-Base repositioning \\
\hline 5 & $\begin{array}{l}\text { Water Supply; Waste, Waste and } \\
\text { Recycling Management }\end{array}$ & 0.83 & 1.53 & Base reposition \\
\hline 6 & Construction & 0.85 & 1.31 & Base reposition \\
\hline 7 & $\begin{array}{l}\text { Wholesale and Retail Trade; Car and } \\
\text { Motorcycle Repair }\end{array}$ & 1.14 & 0.80 & Non-Base repositioning \\
\hline 8 & Transportation and Storage & 0.72 & 0.78 & Non-Base \\
\hline 9 & $\begin{array}{l}\text { Provision of Accommodation and } \\
\text { Food and Drink }\end{array}$ & 1.11 & 1.03 & Stay Base \\
\hline 10 & Information and Communication & 0.66 & 0.95 & Non-Base \\
\hline 11 & Financial Services and Insurance & 0.97 & 0.22 & Non-Base \\
\hline 12 & Real Estate & 0.92 & 1.12 & Base reposition \\
\hline 13 & $\begin{array}{l}\text { Company Services } \\
\text { Mandatory }\end{array}$ & 0.07 & 1.39 & Base reposition \\
\hline 14 & $\begin{array}{l}\text { Administration, Defense, and Social } \\
\text { Security }\end{array}$ & 1.11 & 1.12 & Base \\
\hline 15 & Education Services & 1.61 & 1.07 & Base \\
\hline 16 & Health Services & 1.55 & 1.09 & Base \\
\hline 17 & Other Services & 1.53 & 1.50 & Base \\
\hline
\end{tabular}

Source: Processed data, 2021. 


\section{Shift Share Analysis}

The shift-share analysis is an analysis used to compare the difference in growth rates of various sectors (industries) in a research area with the reference area. This analysis uses the method of isolating various factors that cause industrial changes in an area in its growth from one period of time to the next (Arsyad, 2010). The results of the Shift Share analysis in Rejang Lebong Regency can be seen in the table below.

Table 4. Shift Share Analysis Results

\begin{tabular}{|c|c|c|c|c|c|}
\hline No. & Sector & $\mathrm{Nij}$ & Mij & Cij & Dij \\
\hline 1 & Agriculture, Forestry, and Fisheries & 2418.26 & 297,336 & 161,277 & 2876,868 \\
\hline 2 & Mining and Quarrying & 315,162 & 32.0357 & $-46,065$ & 301.1332 \\
\hline 3 & Processing industry & 514.22 & 88.9012 & $-11,496$ & 591,6255 \\
\hline 4 & Procurement of Electricity and Gas & 6,64924 & 2.85659 & -0.1377 & 9.368093 \\
\hline 5 & $\begin{array}{l}\text { Water Supply; Waste, Waste and } \\
\text { Recycling Management }\end{array}$ & 18.9435 & 2.19492 & 1.9662 & 23.10466 \\
\hline 6 & Construction & 363,309 & 96,601 & 51,8492 & 511.7594 \\
\hline 7 & $\begin{array}{l}\text { Wholesale and Retail Trade; Car and } \\
\text { Motorcycle Repair }\end{array}$ & 1196.98 & 442,211 & $-90,105$ & 1549,089 \\
\hline 8 & Transportation and Storage & 645,609 & 182.04 & $-45,465$ & 782.1846 \\
\hline 9 & $\begin{array}{l}\text { Provision of Accommodation and Food } \\
\text { and Drink }\end{array}$ & 123.47 & 50,4451 & 7,77866 & 181.6937 \\
\hline 10 & Information and Communication & 351.93 & 115,602 & 4,54332 & 472,0758 \\
\hline 11 & Financial Services and Insurance & 285,874 & 27,4707 & $-57,316$ & 256,029 \\
\hline 12 & Real Estate & 370,036 & 67.2971 & 20,574 & 457,9072 \\
\hline 13 & $\begin{array}{l}\text { Company Services } \\
\text { Mandatory Government }\end{array}$ & 182,302 & 39.6832 & 25,8327 & 247,8184 \\
\hline 14 & $\begin{array}{l}\text { Administration, Defense, and Social } \\
\text { Security }\end{array}$ & 718,818 & 161,523 & 46.8313 & 927.1723 \\
\hline 15 & Education Services & 527.37 & 90.7158 & 20.1414 & 638,227 \\
\hline 16 & Health Services & 124,172 & 46.3952 & 11.4721 & 182,0391 \\
\hline 17 & Other Services & 59.3702 & 20,9899 & 15,8641 & 96.22426 \\
\hline & Total & $8,222.48$ & $1,764.30$ & 117.55 & $10,104.32$ \\
\hline
\end{tabular}

Source: Processed data, 2021.

In the results of the Shift Share analysis above, it can be seen that the Nij value of all sectors is positive, this indicates that growth Rejang Lebong Regency is growing faster than the average growth of Bengkulu Province. For the Mij value, all sectors are positive and equal to $\mathrm{Nij}$, so it can be seen that all advanced sectors in the Regency are growing faster than the overall economic growth. The Cij value in Rejang Lebong Regency is known that there are sectors that have positive and negative values. The sectors that have the largest and most positive Cij values are in the Agriculture, Forestry, and Fisheries sectors, this shows that these sectors have high competitiveness in Bengkulu Province.

\section{Overlay Analysis}

Overlay or combined analysis is an analysis that is used to determine the final result of a combination of the three analysis tools. The analysis used in this study is LQ, DLQ, and Shift Share. The results obtained are as follows: 
Table 5. Results of Overlay Analysis

\begin{tabular}{|c|c|c|c|c|c|}
\hline No. & Information & LQ & DLQ & $\begin{array}{l}\text { Shift } \\
\text { Share }\end{array}$ & Conclusion \\
\hline 1 & Agriculture, Forestry, and Fisheries & + & + & + & Superior \\
\hline 2 & Mining and Quarrying & - & - & - & Not Featured \\
\hline 3 & Processing industry & - & - & - & Not Featured \\
\hline 4 & Procurement of Electricity and Gas & + & - & - & Not Featured \\
\hline 5 & $\begin{array}{l}\text { Water Supply; Waste Management, } \\
\text { Limdah, And Recycling }\end{array}$ & - & + & + & Not Featured \\
\hline 6 & Construction & - & + & + & Not Featured \\
\hline 7 & $\begin{array}{l}\text { Wholesale and Retail Trade; Car and } \\
\text { Motorcycle Repair }\end{array}$ & + & - & - & Not Featured \\
\hline 8 & Transportation and Storage & - & - & - & Not Featured \\
\hline 9 & $\begin{array}{l}\text { Provision of Accommodation and Food } \\
\text { and Drink }\end{array}$ & + & + & + & Superior \\
\hline 10 & Information and Communication & - & - & + & Not Featured \\
\hline 11 & Financial Services and Insurance & - & - & - & Not Featured \\
\hline 12 & Real Estate & - & + & + & Not Featured \\
\hline 13 & Company Services & - & + & + & Not Featured \\
\hline 14 & $\begin{array}{l}\text { Mandatory Government Administration, } \\
\text { Defense, and Social Security }\end{array}$ & + & + & + & Superior \\
\hline 15 & Education Services & + & + & + & Superior \\
\hline 16 & Health Services & + & + & + & Superior \\
\hline 17 & Other Services & + & + & + & Superior \\
\hline
\end{tabular}

Source: Processed data, 2021.

In the table above, it is known that a sector that has a positive LQ, DLQ, and Shift-share value $(+)$ means that the sector has the potential to be the leading sector in Rejang Lebong Regency. From the three analysis tools, it is known that the sectors in Rejang Lebong Regency have positive values, namely in the Agriculture, Forestry, and Fisheries sectors; Provision of accommodation and food and drink; Defense and Compulsory Social Security; Education Services; Health Services and Other Services. The agricultural sector is one of the sectors that has a high GRDP value so that it can obtain positive $L Q$, DLQ and shift-share values so that it becomes a leading sector. The same thing also happened in Kendal Regency which was researched by Wahyuningtyas et al (2013) who stated that the Agriculture, Forestry and Fisheries sector in Kendal Regency was also a leading sector because it provided a good contribution to GRDP. The sector can compete with the reference regions. Not only the agriculture, forestry, and fisheries sectors, other sectors which are leading sectors in Rejang Lebong Regency are also able to compete with the reference area

\section{CONCLUSION}

From the research that has been carried out in the research title "Analysis of Economic Structure and Leading Sectors in Rejang Lebong Regency" several conclusions are obtained, namely:

The economic structure of GRDP according to business fields based on current prices and constant prices in 20152016 shows that the sectors that have the greatest value are in the Agriculture, Forestry, and Fisheries sectors with a value between $29 \%-33 \%$. For the sector that contributed the smallest GRDP to Rejang 
Lebong Regency, namely the Gas and Electricity Procurement sector which had a value of only $0.1 \%-0.2 \%$.

Leading sectors that have positive values from the three analysis tools through LQ, DLQ, and Shift Share in Rejang Lebong Regency are the Agriculture, Forestry and Fisheries sectors; Provision of accommodation and food and drink; Defense and Compulsory Social Security; Education Services; Health Services and Other Services. From the above conclusions, it can be suggested that hopefully the value of the Gross Regional Domestic Product of Rejang Lebong Regency can be increased every year. Especially for sectors that have a low GRDP value. So the Rejang Lebong Regency can increase economic growth for regional economic development.

\section{REFERENCES}

Arsyad, L. (2010). Economic Development .The Publishing and Printing Section of STIM YKPN. Yogyakarta.

Central Bureau of Statistics. (20122016). Sampang Regency Gross Regional Domestic Product according to business fields. Bengkulu.

Central Bureau of Statistics. (20152019). Rejang Lebong Regency / City Gross Domestic Product according to business fields. Bengkulu.

Hajeri, Erlinda Yurisinthae, Eva Dolorosa. (2015). Analysis of Determination of Leading Economic Sectors in Kubu Raya Regency. Journal of Business Economics and Entrepreneurship, 4 (2), 253-269.
Isabhandia, Y.M., \& Setiartiti, L. (2021). Basic Sector Analysis and Devel opment Strategy of Regional Economic Potential in Kulon Progo District 2013-2017. Journal of Economics Research and Social Sciences, 5(1), 77-87.

Sincere, Tambunan. (2003). Indonesian Economy, Several Important Issues. Bogor. Ghalia Indonesia.

Situmorang, Tulus Hartatio, Sriyoto, Ketut Sukiyono. (2020). Economic Leading Sectors And Competitiveness In South Tapanuli Regency. JASEB, 2 (1), 45-58.

Soeparmoko. (2002). Public Economy for Finance and Regional Development. First edition. Yogyakarta. Andi.

Sukiyono, K. (2010) . Modeling Perekonomian Regional: Pendekatan Model Input-output dan Aplikasinya. BPFP. Universitas Bengkulu. ISBN 978602-96609-4-4

Suyatno. (2000). Economic Base Analysis on regional economic growth level II Wonogiri. Journal of Development Economics, 1 (2), 144-159.

Wahyuningtyas, R., A. Rusgiyono, and Y. Wilandari. (2013). Analysis of Leading Sectors Using PDRB Data. Jurnal Gaussian, 2 (3), 219228.

Widodo, (2006). Development Planning: Computer Applications (Regional Autonomy Era). Yogyakarta. UPP STIM YKPN. 